\title{
Physiological adjustments, fiber yield and quality of colored cotton BRS Topázio cultivar under leaf silicon spraying
}

\author{
Ajustes fisiológicos, rendimento e qualidade de fibras de algodão colorido \\ cultivar BRS Topázio sob pulverização foliar de silício
}

\author{
Rener Luciano de Souza Ferraz ${ }^{1 *}\left(\mathbb{D}\right.$, Patrícia da Silva Costa ${ }^{(D}$, Ivomberg Dourado Magalhães ${ }^{3}$, \\ Aldair de Souza Medeiros ${ }^{4}(-)^{-}$, Pedro Roberto Almeida Viégas ${ }^{5}$, Alberto Soares de Melo $^{6}$ (i)
}

\author{
${ }^{1}$ Universidade Federal de Campina Grande/UFCG, Sumé, PB, Brasil \\ ¿Universidade Federal de Campina Grande/UFCG, Campina Grande, PB, Brasil \\ ${ }^{3}$ Universidade Federal de Alagoas/UFAL, Maceió, AL, Brasil \\ ${ }^{4}$ Universidade de São Paulo/USP, Piracicaba, SP, Brasil \\ 5Universidade Federal de Sergipe/UFS, São Cristóvão, SE, Brasil \\ Universidade Estadual da Paraíba/UEPB, Campina Grande, PB, Brasil \\ *Corresponding author: ferragroestat@gmail.com \\ Received in March 18, 2021 and approved in June 2, 2021
}

\begin{abstract}
Abiotic stresses reduce the yield and quality of cotton production, however, this problem may be mitigated by exogenous elicitors. This study investigated physiological adjustments, improvement in productivity, and fiber yield and quality from naturally colored cotton BRS Topázio cultivar under leaf silicon spraying. Five doses of silicon $\left(0,50,100,150\right.$, and $\left.200 \mathrm{mg} \mathrm{L}^{-1}\right)$ were tested in a completely randomized design. The variables assessed were physiological, production, fiber yield and quality. Data were submitted to principal component analysis, multivariate and univariate variance, and multiple linear regression. Silicon promotes physiological adjustments, increased production, cotton fiber yield and quality. Optimum silicon dose varies depending on the variable response. Fiber quality from plants treated with silicon is within the expected pattern for this cultivar and the international standard D-4605 of the American Society for Testing and Materials. Therefore, planting BRS Topázio cultivar under silicon foliar applications may be recommended to improve the naturally colored fiber cotton production chain in the Brazilian semiarid region.
\end{abstract}

Index terms: Gossypium hirsutum; semiarid; potassium silicate; fiber technologies.

\begin{abstract}
RESUMO
Estresses abióticos reduzem o rendimento e a qualidade da produção de algodão e isso pode ser atenuado pelo uso de eliciadores exógenos. Este estudo investigou ajustes fisiológicos, melhoria da produtividade, rendimento e qualidade da fibra do algodão naturalmente colorido cultivar BRS Topázio sob pulverização de silício foliar. Foram testadas cinco doses de silício $(0,50,100,150$, $200 \mathrm{mg} \mathrm{L}^{-1}$ ), em delineamento inteiramente casualizado; e avaliadas variáveis fisiológicas, produção, rendimento e qualidade de fibra. Os dados foram submetidos às análises de componentes principais, variância multivariada e univariada e regressão linear múltipla. O silício promove ajustes fisiológicos, aumento de produção, rendimento e qualidade de fibra de algodão. A dose ideal de silício varia em função da variável resposta avaliada. A qualidade da fibra de plantas tratadas com silício está dentro dos valores esperados para a cultivar e em conformidade com a norma internacional D-4605 da American Society for Testing and Materials. Portanto, o plantio da cultivar BRS Topázio com aplicações foliares de silício pode ser recomendado para melhoria da cadeia produtiva de algodão de fibra naturalmente colorida no semiárido do Brasil.
\end{abstract}

Termos para indexação: Gossypium hirsutum; semiárido; silicato de potássio; tecnologia de fibras.

\section{INTRODUCTION}

Climatic changes cause abiotic stresses in plants and trigger physiological changes which reduce the production and quality of agricultural products. This scenario shows a growing demand for food, fibers, and bioenergy and draws attention to cultivated species with multiple applications, such as naturally colored fiber (NCF) cotton (Gossypium hirsutum L.) (Soares et al., 2021)

Annually, more than 25.9 million tonnes of seed cotton are produced in more than 70 countries, mainly the white fiber cotton cultivars (Erpelding, 2021). The dyeing of this fiber can cause damage to human health and the environment, which suggests that NCF cultivars are 
environmentally friendly, although they have lesser fiber production and quality (Chen et al., 2021).

Research is required to increase the supply and quality of NCF (Cardoso et al., 2021). Cotton cultivars already available, for example, BRS Topázio, may have their fiber yield and quality increased as the stress response mechanisms are known (Guo et al., 2021; Saleem et al., 2021; Trishla; Kirti, 2021) and exogenous attenuators are applied to plants (Hamani et al., 2021).

Elicitors of abiotic stresses, such as silicon ( $\mathrm{Si}$ ), can be used to increase growth, yield, and the quality of plant production, because Si acts on plant's physiology and activates the antioxidant defense mechanism to eliminate reactive oxygen species (ROS) by the action of enzymes, as well as influences osmoregulatoty and chloroplast pigments synthesis (Shahzad et al., 2021).

Based on this information, it can be assumed that NCF production and quality may be enhanced by $\mathrm{Si}$ because this element is present from anthesis up to fiber development (Boylston, 1988; Boylston et al., 1990). This study investigates physiological adjustments, productivity improvement, and fiber yield and quality of naturally colored cotton BRS Topázio cultivar under leaf silicon spraying.

\section{MATERIAL AND METHODS}

\section{Area and experimental design}

The research was carried out in Embrapa Cotton experimental area, located in the micro-region of Campina
Grande, Paraíba state, at geographic coordinates: $07^{\circ} 13^{\prime}$ South latitude and $53^{\circ} 31^{\prime}$ 'West longitude, an altitude of 551 meters, with semiarid equatorial climate, average temperature $25^{\circ} \mathrm{C}$ and relative air humidity varying between 72 and $91 \%$. Meteorological data such as air temperature, relative air humidity, and rainfall were collected from an automated agrometeorological station located $100 \mathrm{~m}$ from the trial area. Daily heat stroke (DHS) values, in hours per day, were obtained from the quotation of heiograph tapes, model Campbell-Stocke.

During the trial period were observed: average $0.5 \pm 1.6 \mathrm{~mm}$ per day and accumulated $69.6 \mathrm{~mm}$ rainfall; minimum $20.2 \pm 1.0^{\circ} \mathrm{C}$, average $23.4 \pm 0.9^{\circ} \mathrm{C}$, and maximum $29.4 \pm 1.5{ }^{\circ} \mathrm{C}$ air temperatures; relative air humidity $77.5 \pm 4.6 \%$; daily sunshine $8.1 \pm 2.0$ hours; and average $4.8 \pm 1.3 \mathrm{~mm}$ per day, and accumulated 738.8 mm evaporation class ' $A$ ' tank (Figure 1). This variability characterizes Brazilian Northeast weather, which requires adequate management for greater cotton yield.

Given the above, indicates the possibility of abiotic stresses in the cotton during the experimental period, such as water, thermal, and saline, which may have limited cotton fiber yield and quality (Abdelraheem et al., 2019; Sharif et al., 2019; Sun et al., 2019), especially in plots that did not receive $\mathrm{Si}$, because this element acts to induce stress tolerance in plants (Khan et al., 2020), increasing photosynthesis, stomatal conductance, and efficiency in water use with positive results in cotton production (Barros et al., 2019).

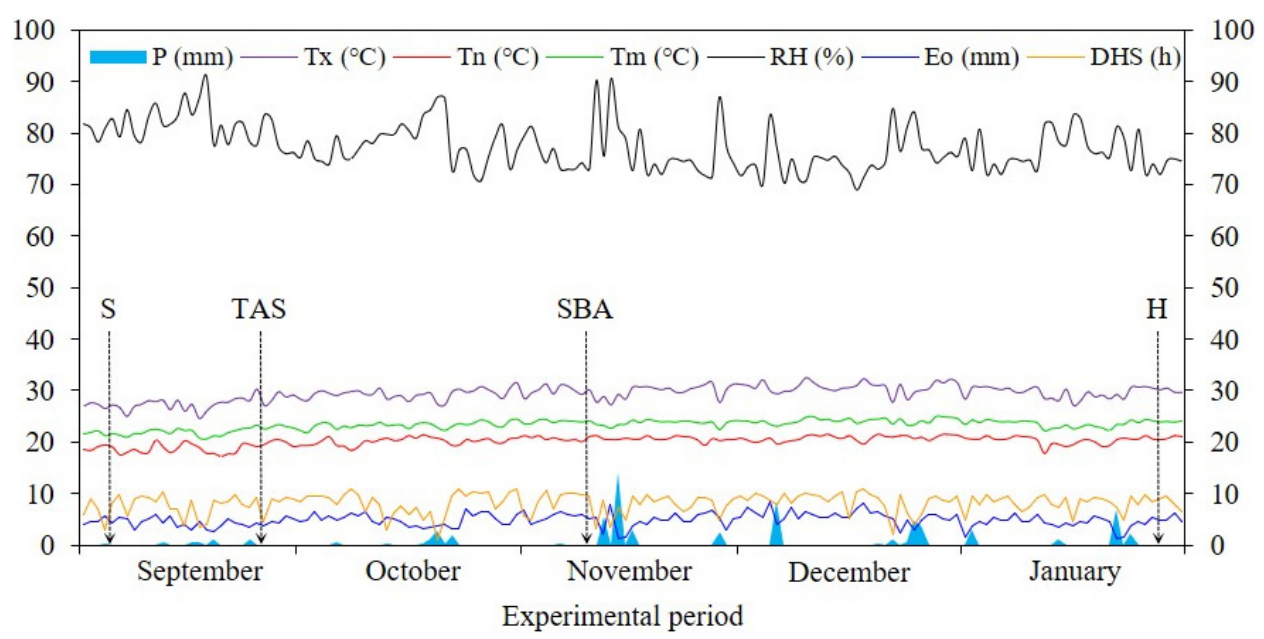

Figure 1: Meteorological variables recorded during the experimental period in Campina Grande, PB, Brazil. P - Precipitation; Tm - Mean air temperature; Tn - Minimum air temperature; Tx - Maximum air temperature; RH - Mean relative air humidity; Eo - Class 'A' tank evaporation; DHS - Daily heat stroke; S - Sowing; TAS - Treatment application start; SBA - Sampling for biochemical analysis and $\mathrm{H}$ - Harvest. 
The experimental design was completely randomized with five doses of silicon $(0,50,100,150$, and $200 \mathrm{mg} \mathrm{L}^{-1}$ of Si) and four replicates with a total of 20 experimental plots for BRS Topázio cotton cultivar; this cultivar was developed by Embrapa Cotton Improvement Program (Carvalho; Andrade; Silva Filho, 2011). Si doses were obtained by diluting potassium silicate $\left(\mathrm{K}_{2} \mathrm{SiO}_{3}\right)$ in distilled water. Silicon source $\left(\mathrm{Sifol}^{\mathbb{}}{ }^{\text {) }}\right.$ was a liquid solution composed of $12 \% \mathrm{Si}$ and $15 \% \mathrm{~K}$ and electrical conductivity (EC) $1.93 \mathrm{dS} \mathrm{m}^{-1}$, saline index 26, density $1.40 \mathrm{~g} \mathrm{~L}^{-1}$, and $\mathrm{pH} 10.96$.

The experimental unit consisted of a cotton plant per pot (200 dm in volume) filled with $10 \mathrm{dm}^{3}$ of gravel No. 2 and $180 \mathrm{dm}^{3}$ of soil classified as Fluvent Entisols dystrophic by U.S. Soil Taxonomy (Soil Survey Staff, 2014), and with the following chemical and physical characteristics: $\mathrm{pH}$ in $\mathrm{H}_{2} \mathrm{O}=5.1 ; \mathrm{P}=0.3 \mathrm{mg} \mathrm{dm}^{-3} ; \mathrm{K}^{+}=0.5$ $\mathrm{mmol}_{\mathrm{c}} \mathrm{dm}^{-3} ; \mathrm{Na}^{+}=0.4 \mathrm{mmol}_{\mathrm{c}} \mathrm{dm}^{-3} ; \mathrm{Ca}^{+2}=3.7 \mathrm{mmol}_{\mathrm{c}} \mathrm{dm}^{-3}$; $\mathrm{Mg}^{+2}=6.5 \mathrm{mmol}_{\mathrm{c}} \mathrm{dm}^{-3} ; \mathrm{Al}^{+3}=5.0 \mathrm{mmol}_{\mathrm{c}} \mathrm{dm}^{-3} ; \mathrm{H}^{+}+\mathrm{Al}^{+3}=$ $28.9 \mathrm{mmol}_{\mathrm{c}} \mathrm{dm}^{-3} ; \mathrm{T}=40.0 \mathrm{mmol}_{\mathrm{c}} \mathrm{dm}^{-3} ; \mathrm{V}=28.0 \% ; \mathrm{OM}=$ $3.6 \mathrm{~g} \mathrm{~kg}^{-1} ; \mathrm{N}=0.0 \mathrm{~g} \mathrm{~kg}^{-1}$; sand $=81.44 \%$; silt $=13.79 \%$; clay $=4.77 \%$; soil density $=1.52 \mathrm{~kg} \mathrm{dm}^{-3}$; particle density $=$ $2.85 \mathrm{~kg} \mathrm{dm}^{-3}$; porosity $=46.67 \%$; natural humidity $=0.30 \%$; available water $=1.43 \%$ and sandy loam texture.

Liming based on exchangeable $\mathrm{Al}$ was done with $1.2 \mathrm{t}$ ha $^{-1}$ of dolomitic limestone ( $90 \%$ of total neutralizing power). After liming, the soil was incubated for 60 days, revolved and irrigated weekly and moisture content kept close to $70 \%$ of field capacity. Afterward, N, P, and K fertilizers were applied. $\mathrm{P}$ was applied 15 days before sowing, and $\mathrm{N}$ and $\mathrm{K}$ were split into two applications until flowering.

\section{Planting, plant management, and silicon treatments}

Seeds were treated with Thiram ${ }^{\circledR}$ fungicide on the proportion $500 \mathrm{~g}$ of commercial product for $100 \mathrm{~kg}$ of seeds, afterward, 5 seeds were sown per experimental unit at a $0.03 \mathrm{~m}$ depth. Plant growth regulator was not used. At 15 days after emergence (DAE), seedlings were thinned and, the most vigorous, was selected in each experimental unit.

Initially, irrigation was used to keep soil moisture close to $70 \%$ of field capacity. Replenishment of evapotranspirated water by plants (ETc) was done based on the Class A tank evaporation 'A' (Eo) and the crop coefficient $(\mathrm{Kc})$ throughout the phenological plant stages (Bezerra et al., 2012), using Equation 1.

$\mathrm{ETc}=\mathrm{Eo} * \mathrm{Kc}$

Where:

ETc - crop evapotranspiration $\left(\mathrm{mm} \mathrm{day}^{-1}\right)$
Eo - reference evaporation estimated by Class ' $A$ ' tank $\left(\mathrm{mm}\right.$ day $\left.^{-1}\right)$

Kc - crop coefficient

After 15 DAE, Si was sprayed on leaves weekly, in abaxial and adaxial positions, until the solution drained. Pots surface was covered with plastic canvas to prevent residual silicon effect on the soil, also, a surfactant was utilized to increase the efficiency of Si application with a manual compression sprayer with a volume of $5 \mathrm{dm}^{3}$, a piston-type pump, and a $34 \mathrm{~mm}$ diameter nozzle.

\section{Assessments of physiological traits}

During full bloom period (60 DAE), the first leaves, that is, fully expanded and counted from the base of the first branch with a floral bud, were identified, collected, and stored at $-20^{\circ} \mathrm{C}$. Afterward, $113 \mathrm{~mm}^{2}$ leaf discs were collected with a copper hole puncher. These discs were used for chloroplast pigments contents extraction and quantification, intracellular electrolytes leakage, and leaf relative water content.

The methodology proposed by Arnon (1949) and adapted by Hiscox and Israelstam (1979) was used to extract chlorophylls $a$ (Chla), $b$ (Chlb), and total (Chlt). Total carotenoids (Tcar) were quantified using the equation described by Wellburn (1994).

Intracellular electrolytes leakage (IEL) was assessed by the methodology described by Brito et al. (2011). After incubation, the electrical conductivity of the medium $\left(\mathrm{EC}_{\mathrm{i}}\right)$ was measured with a conductivity meter (W12D, BEL ENGINEERING, Italy). Then, these samples were submitted to $80{ }^{\circ} \mathrm{C}$ for 90 minutes in an oven, and the conductivity was measured again $\left(\mathrm{EC}_{\mathrm{f}}\right)$, as well, the electrolytic leakage was quantified by Equation 2 .

$\mathrm{IEL}=\left(\frac{\mathrm{EC}_{\mathrm{i}}}{\mathrm{EC}_{\mathrm{f}}}\right) * 100$

Where:

IEL - intracellular electrolyte leakage (\%)

$\mathrm{EC}_{\mathrm{i}}$ - initial electrical conductivity of the medium $\left(\mathrm{dS} \mathrm{m}^{-1}\right)$ $\mathrm{EC}_{\mathrm{f}}$ - final electrical conductivity of the medium $\left(\mathrm{dS} \mathrm{m}^{-1}\right)$

Relative water content in the leaf (RWC) was quantified by the methodology described by Brito et al. (2011), Equation 3.

$\mathrm{RWC}=\left(\frac{\mathrm{DFM}-\mathrm{DDM}}{\mathrm{DTM}-\mathrm{DDM}}\right) * 100$ 
Where:

RWC - relative water content in the leaf $(\%)$

DFM - disc fresh matter mass (g)

DDM - disc dry matter mass (g)

DTM - disc turgid matter mass (g)

\section{Fiber yield and quality assessments}

Manual cotton harvesting was carried out at 145 DAE when the number of bolls per plant (NBO, per plant) was quantified. Harvested material was weighed on a scale (accuracy of $0.001 \mathrm{~g}$ ) to quantify the boll mass per plant (BMP, g) and the average mass of one boll (AMB, g). The harvest index (HI) was obtained with the relationship between BMP and shoot dry matter weight according to Hussein, Janat and Yakoub (2011), Equation (4).

$$
\mathrm{HI}=\left(\frac{\mathrm{BMP}}{\mathrm{SDM}}\right)
$$

Where:

HI - harvest index, dimensionless

BMP - bolls mass per plant (g)

SDM - shoot dry matter mass (g)

Cotton samples quality was measured with an HVI (High Volume Instrument) by determining the upper half mean length (UHM, mm), fiber length uniformity index (FUI, $\%$ ), short fiber index (SFI, \%), specific strength or toughness of fiber (STR, gf tex ${ }^{-1}$ ), elongation at break fiber (ELG, \%), micronaire fiber index (MIC, $\mu \mathrm{g} \mathrm{in}^{-1}$ ), fiber maturity index (FMI), and count strength product or reliability index (CSP, \%) (Almeida et al., 2011). The classification was evaluated by the standard values of each cultivar (Carvalho; Andrade; Silva Filho, 2011), by the cotton fiber quality manual (Lima, 2018), and HVI test results (Fonseca; Santana, 2002) according to the American Society for Testing and Materials international standard D-4605.

\section{Statistical analysis}

Data were submitted to the normality test, which were standardized to obtain zero mean $(=0.0)$ and unit variance $\left(\mathrm{s}^{2}=1.0\right)$ and submitted to exploratory Principal Component Analysis (PCA). To discuss the main components (PCs), eigenvalues greater than the unit $(\lambda>1.0)$ was considered, according to Kaiser (1960), which could explain more than $10 \%$ of the total variance (Govaerts et al., 2007).

Correlation coefficient (r) variables greater than 0.65 were maintained PC (Hair Jr. et al., 2009). Not associated variables with PCs $(\mathrm{r}<0.65)$ were removed from the standardized database and a new analysis was performed.
Variables on each PC were submitted to multivariate analysis of variance (MANOVA) by Roy's test $(\mathrm{P}<0.05)$. Not associated original variables data with PCs were submitted to univariate analysis of variance (ANOVA) by $\mathrm{F}$ test $(\mathrm{P}<0.05)$. Statistical analyzes were processed with the software Statistica v. 7.0 (Statsoft, 2004).

Variables data of each PC were submitted to multiple linear regression analysis (MLRA), considering each variable of fiber quality as a dependent variable and, the other variables contained in the same PC, plus the doses of $\mathrm{Si}$, as independent variables, to adjust forecasting models for fiber quality variables. The multiple linear regression model (Equation 5) was used with $\mathrm{k}$ independent variables:

$\mathrm{FQV}=\alpha+\sum_{\mathrm{i}=1}^{\mathrm{K}} \beta_{\mathrm{i}} \mathrm{X}_{\mathrm{ij}}+\varepsilon_{\mathrm{j}}$

Where:

FQV - fiber quality variable

$\alpha$ - linear coefficient

$\beta \mathrm{i}-$ regression coefficient of the independent variables

$X \mathrm{ij}$ - independent variables $\mathrm{Xi}$ in observation $\mathrm{j}$

$\varepsilon j$ - error associated to FQV in observation $j$

$\mathrm{K}$ - number of independent variables (Barbosa et al., 2019)

\section{RESULTS AND DISCUSSION}

\section{Formation of principal components and silicon effect}

PCAs and MANOVAs results are shown in Table 1. The multiple dimensions, represented by 18 original variables evaluated were condensed into two dimensions, represented by the principal components $\left(\mathrm{PC}_{1}\right.$ and $\left.\mathrm{PC}_{2}\right)$ with eigenvalues greater than the unit $(\lambda>1.0)$. There was a significant effect $(p<0.01)$ of $\mathrm{Si}$ doses in two PCs.

For BRS Topázio cultivar, $\mathrm{PC}_{1}$ and $\mathrm{PC}_{2}$ together accounted for $89.43 \%$ of $\mathrm{s}^{2}$, in which $\mathrm{PC}_{1}$ was responsible for $47.89 \%$ of $\mathrm{s}^{2}$ and was formed by the combination of RWC, BMP, and fiber quality variables (UHM, FUI, SFI, STR, ELG, and CSP), while PC had $41.53 \%$ of $\mathrm{s}^{2}$ and was formed by chlorophylls (Chla, Chlb, and Chlt), intracellular electrolytes leakage (IEL), production and yield of bolls (NBO and AMB), and fiber quality indices (MIC and IMF). The loss of information was $10.57 \%$ of $\mathrm{s}^{2}$. The Tcar, and HI were not associated with PCs.

The reduction of 18 original variables into two constructed variables (PCs) is important in understanding 
the Si effect from all the joint variables, because the PCA is efficient in reducing many variables into smaller subspace with minimal information loss (Alkarkhi; Alqaraghuli, 2020; Saccenti; Camacho, 2020; Kherif; Latypova, 2020). Thus, PCA application was efficient in this research, since, with both PCs, it was possible to explain high proportions of $\mathrm{s}^{2}(89 \%)$ with low information losses $(11 \%)$.

In cotton, Asha et al. (2013) verified the formation of 7 PCs $(\lambda>1.0)$ to explain $87.98 \%$ of $\mathrm{s}^{2}$, when they evaluated 40 genotypes and 15 variables; Nazir et al. (2013) found 3 PCs with $64.1 \%$ of s $\mathrm{s}^{2}$, when they evaluated 70 genotypes and 7 variables; Shakeel et al. (2015) found that 4 PCs explained $65.2 \%$ of $\mathrm{s}^{2}$ in 50 genotypes and 12 variables; Rathinavel (2018) found 8 PCs with $83.1 \%$ of $\mathrm{s}^{2}$ when 101 varieties and 21 variables were evaluated; and Rathinavel (2019) found that 5 PCs explained 76.8\% of $\mathrm{s}^{2}$, when they evaluated 340 germplasm accesses and
14 variables. The greater number of PCs found by these researchers was due to the huge number of accessions, genotypes, and varieties studied.

\section{Physiological adjustments, yield and cotton quality of BRS Topázio cultivar}

In $\mathrm{PC}_{1}$, cotton treated with $100 \mathrm{mg} \mathrm{L}^{-1}$ of Si showed a higher RWC (70.7\%) and produced a greater BMP (123 $\mathrm{g}$ ), whereas, in the dose of $50 \mathrm{mg} \mathrm{L}^{-1}$ of Si there was fiber production with higher SFI (9.74\%) and ELG (7.40\%). These results are different from $55.61 \%, 116.75 \mathrm{~g}, 7.60 \%$, and $5.34 \%$ that were recorded in the control treatment of the respective variables. Control plants produced fibers with significant values of UHM (29.49 mm), CSP $(2,897.92 \%)$, STR (31.59 gf tex $\left.{ }^{-1}\right)$, and FUI (84.69\%), however, there was a reduction with 50 and $100 \mathrm{mg} \mathrm{L}^{-1}$ of Si which was followed by increases of $29.08 \mathrm{~mm}, 2,883.2 \%, 30.89 \mathrm{gf} \mathrm{tex}^{-1}$, and $84.72 \%$ with $150 \mathrm{mg} \mathrm{L}^{-1}$ of $\mathrm{Si}$ (Figure 2).

Table 1: Correlation among original variables and main components, eigenvalues, explained and accumulated variance, and probability significance of hypothesis test.

\begin{tabular}{|c|c|c|}
\hline \multirow{2}{*}{ EV - Evaluated Variables } & \multicolumn{2}{|c|}{ Principal Components } \\
\hline & $\mathrm{PC}_{1}$ & $P C_{2}$ \\
\hline Chla - Chlorophyll ' $a$ ' & 0.39 & $0.79^{*}$ \\
\hline Chlb - Chlorophyll 'b' & -0.41 & $-0.87^{*}$ \\
\hline Chlt - Chlorophyll 'total' & 0.38 & $0.77^{*}$ \\
\hline IEL - Intracelular electrolyte leakage & -0.12 & $-0.98^{*}$ \\
\hline RWC - Relative water content & $0.74^{*}$ & 0.28 \\
\hline NBO - Number of bolls & 0.29 & $0.80^{*}$ \\
\hline AMB - Average mass of boll & 0.26 & $-0.88^{*}$ \\
\hline BMP - Boll mass per plant & $0.90^{*}$ & -0.16 \\
\hline UHM - Upper half mean length & $-0.97^{*}$ & 0.18 \\
\hline FUI - Fiber length uniformity index & $-0.73^{*}$ & 0.66 \\
\hline SFI - Short fiber index & $0.99^{*}$ & -0.11 \\
\hline STR - Specific strength or toughness of fiber & $-0.94^{*}$ & -0.24 \\
\hline ELG - Elongation at break fiber & $0.95^{*}$ & -0.32 \\
\hline MIC - Micronaire fiber index & 0.58 & $-0.81^{*}$ \\
\hline FMI - Fiber maturity index & -0.35 & $-0.93^{*}$ \\
\hline CSP - Count strength product or reliability index & $-0.98^{*}$ & 0.17 \\
\hline$\lambda-$ Eigenvalues & 7.66 & 6.65 \\
\hline$s^{2}(\%)$ - Explained variance & 47.89 & 41.53 \\
\hline $\mathrm{s}^{2}(\%)-$ Accumulated variance & 47.89 & 89.42 \\
\hline Roy's test ( $p$ valor) & $<0.01$ & $<0.01$ \\
\hline
\end{tabular}

\footnotetext{
* - Variable considered relevant in each main component $(r \geq 0.74)$.
} 


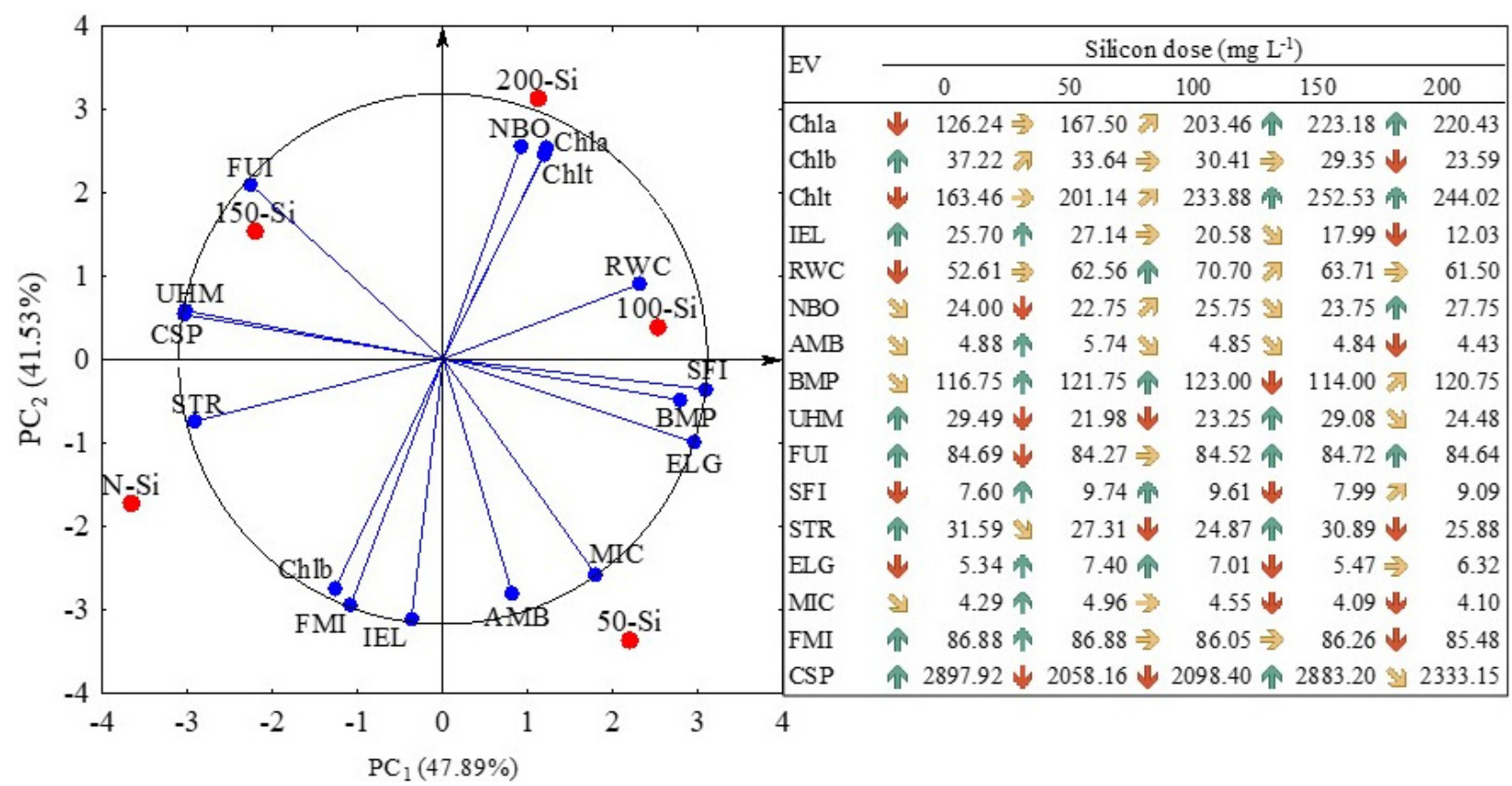

Figure 2: Two-dimensional coordinates projection (biplot) of silicon doses and variables correlation coefficients with the first two principal components $\left(\mathrm{PC}_{1}\right.$ and $\mathrm{PC}_{2}$ ) and average variables.

In $\mathrm{PC}_{2}$, the highest content of Chla $(223.18 \mu \mathrm{mol}$ $\left.\mathrm{m}^{-2}\right)$, Chlt $\left(252.53 \mu \mathrm{mol} \mathrm{m}^{-2}\right)$, and NBO (27.75 bolls) was quantified when the plants received 150 and 200 $\mathrm{mg} \mathrm{L}^{-1}$ of Si, differing from $126.24 \mu \mathrm{mol} \mathrm{m}^{-2}, 163.46$ $\mu \mathrm{mol} \mathrm{m}{ }^{-2}$, and 24 bolls obtained in the control treatment. Plants not treated with Si had the highest Chlb content $\left(37.22 \mu \mathrm{mol} \mathrm{m}^{-2}\right)$ compared to $23.59 \mu \mathrm{mol} \mathrm{m}^{-2}$ content that was registered when the dose $200 \mathrm{mg} \mathrm{L}^{-1}$ of Si was applied (Figure 2).

These results validate importance of $\mathrm{Si}$ on physiological adjustments, growing yield, and NCF quality, because these doses increased the RWC and induced the greater synthesis of Chla and Chlt, the raise in NBO, and BMP production, because treated plants reduced their absolute growth rate and height (Ferraz et al., 2017) and maintained high photosynthetic activity (Ferraz et al., 2014), allowing photoassimilates to be translocated to growing reproductive organs.

The greatest intracellular electrolytes leakage in untreated plants may be due to the action of hydroxyl radical $\left({ }^{*} \mathrm{OH}\right)$, superoxide radical $\left(\mathrm{O}_{2}{ }^{*}\right)$, and hydrogen peroxide $\left(\mathrm{H}_{2} \mathrm{O}_{2}\right)$ in mitochondria, chloroplasts, and peroxisomes, occurrence that has caused membranes, Chla and Chlt degradation, which could be explained by rise in Chlb content (Gill; Tuteja, 2010; Bharwana et al., 2013).
It is possible that BRS Topázio cultivar, not treated with $\mathrm{Si}$, has activated the enzymatic antioxidant system (superoxide dismutase - SOD, ascorbate peroxidase - APX, and catalase - CAT) and the non-enzymatic system, in which chlorophylls and carotenoids are included (Lichtenthaler, 1987; Miller et al., 2011), once these plants produce longer, more uniform and resistant fibers, and higher reliability index.

As for fiber quality (UHM, FUI, STR, and MIC) plants treated with $\mathrm{Si}$ is close to the reference values for BRS Topázio cultivar (Carvalho; Andrade; Silva Filho, 2011). These reference values are short, uniform, medium strength, thick, medium short fiber index, high elongation at break, mature, and very high-reliability index (Almeida et al., 2011; Lima, 2018; Fonseca; Santana, 2002).

ANOVA results indicate that $\mathrm{Si}$ doses had a significant effect on Tcar content. Plants not treated with Si $\left(0 \mathrm{mg} \mathrm{L}^{-1}\right)$ had a Tcar content $97.2 \mu \mathrm{mol} \mathrm{m}^{-2}$ and an increase was observed to $167.55 \mu \mathrm{mol} \mathrm{m} \mathrm{m}^{-2}$ with the estimated dose of $118.62 \mathrm{mg} \mathrm{L}^{-1}$ of Si, however, from this point, the maximum dose $200 \mathrm{mg} \mathrm{L}^{-1}$ of Si has reduced Tcar content to $134.44 \mu \mathrm{mol} \mathrm{m}^{-2}$ (Figure 3). The harvest index (HI) was not influenced by Si doses and presented an average value 0.41 . 
The increase in accessory pigment content (Tcar) due to the increase in Si doses up to $118.62 \mathrm{mg} \mathrm{L}^{-1}$, suggests that $\mathrm{Si}$ has a key role in the photoprotection of photosynthetic apparatus of BRS Topázio cultivar, which can be explained by reducing the transpiratory rate and increasing $\mathrm{CO}_{2}$ assimilation rate, while part of the excitation energy pigment was lost in light emission form, chiefly due to the increase in the variable $(\mathrm{Fv})$ and the maximum $(\mathrm{Fm})$ fluorescence (Ferraz et al., 2014). Both in cotton under stress and that in the control treatment, Si enhances carotenoids levels, as reported by Bharwana et al. (2013).

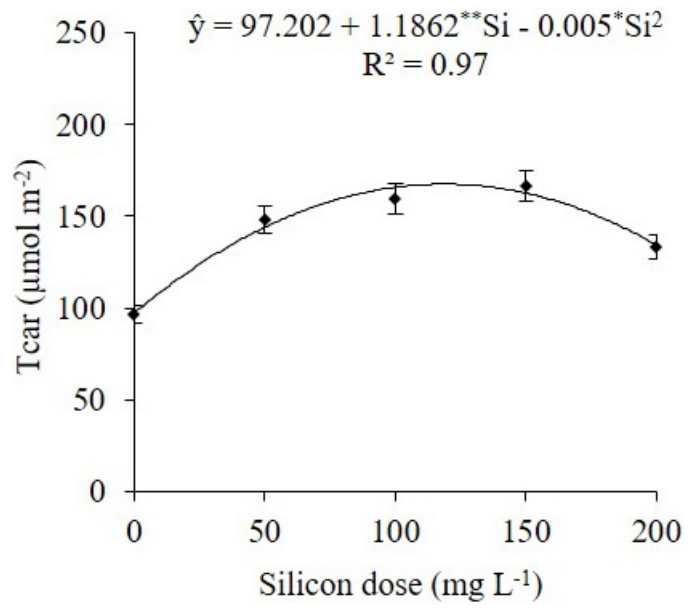

Figure 3: Total carotenoids content in BRS Topázio cultivar leaves as a function of silicon doses.

${ }^{*}$, and ${ }^{* *}$ significat at $\mathrm{p}<0.05$ and $\mathrm{p}<0.01$.

\section{Multivariate adjustment models of fiber quality prediction}

Physiological variables (chloroplastid pigments, relative water content in the leaves, and leakage of intracellular electrolytes), assessed throughout the flowering, as well as, the cotton production and yield components (number of bolls, average boll mass, boll mass per plant, and harvest index) attained at 145 DAS, are not good regressors for predicting the cotton fiber quality naturally colored, because the multiple linear regression models, with significant adjustment, were not obtained, except for SFI, despite having a significant adjustment $(\mathrm{P}<0.05)$, had a low coefficient of determination (Table 2).

In this study, the search to adjust fiber quality forecasting models is supported by the necessity to anticipate important information for decision-making and planning crop management in the field (Balaji Prabhu; Dakshayini, 2020), because, according to Alkarkhi and Alqaraghuli (2020), multiple linear regression models are efficient to explain large amounts of correlated variables. On the other hand, Hope (2020) highlights the possibility of these models may fail when many predictor variables are studied.

Using PCA and MLRA to assess soil quality indicators in long-term management systems (20 years), Barbosa et al. (2019) adjusted models for predicting urease and amylase enzymes activity, with good prognostic capacity. Magalhães et al. (2019) adjusted models for bean production components prediction according to irrigation levels and growth variables.

Sawan (2013), for cotton plants, adjusted multiple linear regression models to predict production components as a function of climatic variables. This researcher have pointed out that it is possible to minimize the injurious effects of abiotic stresses by using appropriate management practices (adequate irrigation regime and specific plant growth regulators). So, there is a clear need for further research involving more variables for quality forecasting models of naturally colored cotton fibers.

Table 2: Summary of multiple regression analyzes for fiber quality variables as a function of Si doses and other variables for each PC.

\begin{tabular}{cllllllll}
\hline \multirow{2}{*}{ Multiple regression } & \multicolumn{7}{c}{ Fiber quality variables } \\
\cline { 2 - 9 } & UHM & FUI & SFI & STR & ELG & MIC & FMI & CSP \\
\hline Significance probability (P value) & $0.13^{\text {ns }}$ & $0.16^{\text {ns }}$ & $0.03^{*}$ & $0.13^{\text {ns }}$ & $0.06^{\text {ns }}$ & $0.93^{\text {ns }}$ & $0.54^{\text {ns }}$ & $0.06^{\text {ns }}$ \\
R multiple & 0.54 & 0.52 & 0.65 & 0.54 & 0.60 & 0.36 & 0.53 & 0.60 \\
R square & 0.29 & 0.27 & 0.43 & 0.29 & 0.36 & 0.13 & 0.28 & 0.36 \\
R adjusted square & 0.15 & 0.14 & 0.32 & 0.16 & 0.25 & -0.35 & -0.12 & 0.24 \\
Standard error & 3.06 & 1.38 & 1.35 & 3.08 & 0.92 & 0.65 & 1.34 & 380.93 \\
\hline
\end{tabular}

\footnotetext{
* - significant at $\mathrm{p}<0.05$ and ns - not significant.
} 


\section{CONCLUSIONS}

Silicon promotes physiological adjustments, enhance production, yield, and quality of naturally colored cotton fibers of BRS Topázio cultivar grown in the Brazilian semiarid region. The ideal dose of $\mathrm{Si}$ varies depending on the response of evaluated variable. Applications of $50 \mathrm{mg}$ $\mathrm{L}^{-1}$ of $\mathrm{Si}$ are recommended to increase the average mass of a boll and the fibers micronaire index, 100 and $150 \mathrm{mg}$ $\mathrm{L}^{-1}$ of $\mathrm{Si}$ to increase the boll mass production per plant and fiber quality, except micronaire index, and $200 \mathrm{mg} \mathrm{L}^{-1}$ of Si to increase the number of bolls per plant. Fiber quality of plants that have been treated with $\mathrm{Si}$ is within the expected values for this cultivar and by the international standard D-4605 of the American Society for Testing and Materials.

\section{ACKNOWLEDGEMENTS}

This study was financed in part by the Coordenação de Aperfeiçoamento de Pessoal de Nível Superior - Brasil (CAPES) Finance Code 001. The authors would like to thank Prof. Dr. Napoleão Esberard de Macêdo Beltrão (in memoriam) from the Embrapa for his support for research development.

\section{REFERENCES}

ABDELRAHEEM, A. et al. Progress and perspective on drought and salt stress tolerance in cotton. Industrial Crops and Products, 130:18-129, 2019.

ALKARKHI, A. F. M.; ALQARAGHULI, W. A. A. Principal components. In: ALKARKHI, A. F. M.; ALQARAGHULI, W. A. A. Applied statistics for environmental science with $\mathbf{R}$. London: Elsevier Science, v.8, p.133-149, 2020.

ALMEIDA, F. A. C. et al. Desenvolvimento e avaliação de descaroçador para o beneficiamento do algodão. Revista Brasileira de Engenharia Agrícola e Ambiental, 15(6):607-614, 2011.

ARNON, D. I. Copper enzymes in isolated chloroplasts: Polyphenoloxydase in Beta vulgaris. Plant Physiology, 24(1):1-15, 1949.

ASHA, R. et al. Multivariate analysis in upland cotton (Gossypium hirsutum L.). Madras Agricultural Journal, 100(4-6):333335, 2013.

BALAJI PRABHU, B. V.; DAKSHAYINI, M. An effective multiple linear regression-based forecasting model for demand-based constructive farming. International Journal of Web-Based Learning and Teaching Technologies, 15(2):1-18, 2020.
BARBOSA, M. A. et al. Multivariate analysis and modeling of soil quality indicators in long-term management systems. Science of the Total Environment, 657(3):457-465, 2019.

BARROS, T. C. et al. Silicon and salicylic acid in the physiology and yield of cotton. Journal of Plant Nutrition, 42(5):458465, 2019.

BEZERRA, M. V. C. et al. Evapotranspiração e coeficiente de cultura do algodoeiro irrigado a partir de imagens de sensores orbitais. Revista Ciência Agronômica, 43(1):6471, 2012.

BHARWANA, S. A. et al. Alleviation of lead toxicity by silicon is related to elevated photosynthesis, antioxidant enzymes suppressed lead uptake and oxidative stress in cotton. Journal of Bioremediation and Biodegradation 4(4):1000187, 2013.

BOYLSTON, E. K. et al. Role of silicon in developing cotton fibers. Journal of Plant Nutrition, 13(1):131-148, 1990.

BOYLSTON, E. K. Presence of silicon in developing cotton fibers. Journal of Plant Nutrition, 11(12):1739-1747, 1988.

BRITO, G. G. et al. Physiological traits for drought phenotyping in cotton. Acta Scientiarum.Agronomy, 33(1):117-125, 2011.

CARDOSO, D. B. O. et al. Use of computational intelligence in the genetic divergence of colored cotton plants. Bioscience Journal, 37:e37007, 2021.

CARVALHO, L. P.; ANDRADE, F. P.; SILVA FILHO, J. L. Cultivares de algodão colorido no Brasil. Revista Brasileira de Oleaginosas e Fibrosas, 15(1):37-44, 2011.

CHEN, M. et al. Qualitative analysis of cotton fiber pigment composition. Textile Research Journal, 91(3-4):456-463, 2021.

ERPELDING, J. E. Genetic evaluation of the brown fibre phenotype for Gossypium arboreum accession PI 615733. Plant Breeding, 140(2):367-374, 2021.

FERRAZ, R. L. S. et al. Potassium silicate optimizes the growth of naturally colored fiber cotton in the semi-arid. Journal of Experimental Agriculture International, 17(4):1-14, 2017.

FERRAZ, R. L. S. et al. Troca gasosa e eficiência fotoquímica de cultivares de algodão sob aplicação foliar de silício. Semina: Ciências Agrarias, 35(2):735-748, 2014.

FONSECA, R. G.; SANTANA, J. C. F. Resultados de ensaio HVI e suas interpretações (ASTM D-4605). Circular Técnica, 66:1-13, 2002. 
GILL, S. S.; TUTEJA, N. Reactive oxygen species and antioxidant machinery in abiotic stress tolerance in crop plants. Plant Physiology and Biochemistry, 48(12):909930, 2010.

GOVAERTS, B. et al. Influence of permanent raised bed planting and residue management on physical and chemical soil quality in rain fed maize/wheat systems. Plant and Soil, 291(1-2):39-54, 2007.

GUO, A. et al. QTL controlling fiber quality traits under salt stress in upland cotton (Gossypium hirsutum L.). Theoretical and Applied Genetics, 134:661-685, 2021.

HAIRJR., J. F. et al. Análise multivariada de dados. 6. ed., Porto Alegre: Bookman, 2009. 682p.

HAMANI, A. K. M. et al. Application of exogenous protectants mitigates salt-induced $\mathrm{Na}^{+}$toxicity and sustains cotton (Gossypium hirsutum L.) seedling growth: Comparison of glycine betaine and salicylic acid. Plants, 10(2):380, 2021.

HISCOX, J. D.; ISRAELSTAM, G. F. A method for the extraction of chlorophyll from leaf tissue without maceration. Canadian Journal of Botany, 57(12):1332-1334, 1979.

HOPE, T. M. H. Linear regression. In: MECHELLI, A.; VIEIRA, S. Machine learning: Methods and applications to brain disorders. London: Elsevier Science, v.2, p. 67-81, 2020.

HUSSEIN, F.; JANAT, M.; YAKOUB, A. Assessment of yield and water use efficiency of drip-irrigated cotton (Gossypium hirsutum L.) as affected by deficit irrigation. Turkish Journal of Agriculture and Forestry, 35(6):611-621, 2011.

KAISER, H. F. The application of electronic computers to factor analysis. Educational and Psychological Measurement, 20(1):141-151, 1960.

KHAN, A. et al. Silicon-mediated alleviation of combined salinity and cadmium stress in date palm (Phoenix dactylifera L.) by regulating physio-hormonal alteration. Ecotoxicology and Environmental Safety, 188:109885, 2020.

KHERIF, F.; LATYPOVA, A. Principal component analysis. In: MECHELLI, A.; VIEIRA, S. Machine learning: Methods and applications to brain disorders. London: Elsevier Science, v.2, p. 209-225, 2020.

LICHTENTHALER, H. K. Chlorophylls and carotenoids: Pigments of photosynthetic biomembranes. Methods in Enzymology, 148:350-382, 1987.

LIMA, J. J. Classificação do algodão em pluma. In: BELOT, J. L. Manual de qualidade da fibra da AMPA, p. 58-115, 2018.
MAGALHÃES, I. D. et al. Growth, production and yield of common bean underwater replacement levels. Revista Brasileira de Engenharia Agrícola e Ambiental, 23(10):754-760, 2019.

MILLER, G. et al. Reactive oxygen species homeostasis and signaling during drought and salinity stresses. Plant, Cell \& Environment, 33(4):453-467, 2011.

NAZIR, A. et al. Estimation of genetic diversity for CLCuV, earliness and fiber quality traits using various statistical procedures in different crosses of Gossypium hirsutum L. Vestnik OrelGAU, 4(43):1-8, 2013.

RATHINAVEL, K. Agro-morphological characterization and genetic diversity analysis of cotton germplasm (Gossypium hirsutum L.). International Journal of Current Microbiology and Applied Sciences, 8(2):2039-2057, 2019.

RATHINAVEL, K. Principal component analysis with quantitative traits in extant cotton varieties (Gossypium hirsutum L.) and parental lines for diversity. Current Agriculture Research Journal, 6(1):54-64, 2018.

SACCENTI, E.; CAMACHO, J. Multivariate exploratory data analysis using component models. In: CIFUENTES, A. Comprehensive foodomics. London: Elsevier Science, $v$. 2, p. 241-268, 2021.

SALEEM, M. A. et al. Impact of heat stress responsive factors on growth and physiology of cotton (Gossypium hirsutum L.). Molecular Biology Reports, 48:1069-1079, 2021.

SAWAN, Z. M. Applied methods for studying the relationship between climatic factors and cotton production. Journal of Science and Research, 4(11A):37-54, 2013.

SHAHZAD, S. et al. Foliar application of silicon enhances growth, flower yield, quality and postharvest life of tuberose (Polianthes tuberosa L.) under saline conditions by improving antioxidant defense mechanism. Silicon, $1-8,2021$

SHAKEEL, A. et al. Genetic diversity among upland cotton genotypes for quality and yield related traits. Pakistan Journal of Agricultural Sciences, 52(1):73-77, 2015.

SHARIF, I. et al. Salinity stress in cotton: Effects, mechanism of tolerance and its management strategies. Physiology and Molecular Biology of Plants, 25(6):807-820, 2019.

SOARES, L. A. A. et al. Phytomass and production components of colored cotton under salt stress in different phenological stages. Revista Brasileira de Engenharia Agrícola e Ambiental, 25(2):132-138, 2021. 
SOIL SURVEY STAFF. Keys to soil taxonomy. 12.ed., Washington, DC: United States Department of Agriculture, Natural Resources Conservation Service. 2014. 372p.

STATSOFT INC. Statistica: Data analysis software system. version 7, Tulsa, OK, EUA, 2004. Available in: <http// http:// www.statsoft.com/>. Access in: June, 7, 2021.

SUN, H. et al. Genome-wide association mapping of stresstolerance traits in cotton. The Crop Journal, 7(1):77-88, 2019.
TRISHLA, V. S.; KIRTI, P. B. Structure-function relationship of Gossypium hirsutum NAC transcription factor, GhNAC4 with regard to $A B A$ and abiotic stress responses. Plant Science, 302:110718, 2021.

WELLBURN, A. R. The spectral determination of chlorophylls a and $b$, as well as total carotenoids, using various solvents with spectrophotometers of different resolution. Journal of Plant Physiology, 144(3):307-313, 1994. 